\title{
Biochemical Basis for Antibiosis Mechanism of Resistance in Sugarcane to Early Shoot Borer, Chilo infuscatellus Snellen
}

\author{
B. Bhavani ${ }^{*}$, K.D. Reddy ${ }^{1}$, N.V. Rao ${ }^{2}$ and M.B. Lakshmi ${ }^{3}$ \\ Regional Agricultural Research Station \\ Anakapalle, A.N.G.R. Agricultural University \\ India
}

\begin{abstract}
Studies on biochemical basis of resistance of sugarcane to early shoot borer, Chilo infuscatellus Snellen in different sugarcane genotypes, viz., four least susceptible (LS), four moderately susceptible (MS) and four highly susceptible (HS) genotypes in comparison with one susceptible check were carried out under in vitro conditions at Regional Agricultural Research Station, Anakapalle, Andhra Pradesh, India during 2009-10. The results revealed reduced larval survival (26-30\%), weight (79.9-84.6 mg/larva), and prolonged larval period (21.32-22.26 days) on LS genotypes compared to HS genotypes (6484.2\%; 149.3-179.9 mg/larva; 16.56-18.78 days, respectively). The lowest mean growth index was found on LS genotypes (1.53-1.73) compared to HS genotypes (3.51-4.71). Results indicated the presence of antibiosis mechanism in the shoot tissues of LS genotypes either by accumulation of toxins or by the absence of very essential nutrients or feeding stimulant or by the presence of some feeding deterrent. Biochemical analysis indicated that low total sugar (5.34-6.38\%), reducing sugar (0.078-0.089\%) and higher phenol (11.20$12.30 \mathrm{mg} / \mathrm{g})$, neutral detergent fiber (24.09-27.20\%), acid detergent fiber (54.79-57.26\%), lignin (6.61-7.09\%), silica (1.33-1.53\%) and cellulose (25.95-28.58\%) contents in the shoot tissues of LS genotypes (Co 0110, 98 A 165, Co 6806, 98 A 125) increased its resistance to early shoot borer by influencing the biology, establishment of early shoot borer and played an important role in the antibiosis mechanism.
\end{abstract}

Key words: Biology, survival, phenols, silica and total sugars

\section{INTRODUCTION}

Early shoot borer (ESB), Chilo infuscatellus Snellen (Crambidae; Lepidoptera) is a serious pest in peninsular regions of India and a vital pest in early crop growth stages of sugarcane causing an economic loss (Avasthy \& Tiwari, 1986). It destroys 26-65\% of mother shoots (Khan \& Krishnamurthy Rao, 1956) and causes losses of cane yield (22-33\%), sugar recovery $(12 \%)$ and jaggery $(27 \%)$ (Patil \& Hapse, 1981). It infests rainfed sugarcane crop causing 70\% shoot loss (Prasad Rao et al., 1991). In Andhra Pradesh, maximum yield loss could reach $42 \%$ when the incidence was at 60 day-old crop (Lakshminarayana, 1983). It destroys $58 \%$ of shoots in different states, causing reduction of 10.1-34.4 t/ha in cane yield and 0.25-3.0 units in sugar recovery (Chaudhary, 1973).

\footnotetext{
Regional Agricultural Research Station, Palem, Mahaboobnagar, India

Agricultural Research Station, Amadalavalasa, Srikakulam, Inida

Agricultural Polytechnic, Anakapalle, India

Author for correspondence: bhavani72@ymail.com
} 
Management strategies of early shoot borer include the use of resistant varieties. Knowledge on resistance mechanisms and associated factors involved is essential for effective utilization of sources of resistance in the future breeding programmes.

This study was carried out with the objectives of investigating the response of different genotypes and exploring the mechanism and biochemical basis of host plant resistance in different susceptible groups of genotypes against the early shoot borer, C. infuscatellus in sugarcane.

\section{MATERIALS AND METHODS}

\section{Screening of sugarcane genotypes against ESB under field conditions}

Preliminary study on screening of 147 sugarcane genotypes under natural and artificial infestation was carried out to identify the less susceptible genotypes against ESB at Regional Agricultural Research Station (R.A.R.S.), Anakapalle, Andhra Pradesh, India during 200809. Based on the per cent cumulative incidence of ESB, genotypes were graded according to Seshagiri Rao and Krinshnamoorthy (1973) and 12 sugarcane genotypes showing low to high susceptibility to ESB along with the susceptible check (93 A 145) were selected and utilized for further studies.

\begin{tabular}{|c|c|}
\hline Category & Genotypes \\
\hline Least Susceptible (LS) & 98 A 125, 98 A 165, Co 0110 and Co 6806 \\
\hline Moderately susceptible (MS) & 97 A 85, 2000 A 105, 99 A 5 and Co 62175 \\
\hline Highly susceptible (HS) & 93A 11, 99 А 33, 94 A 124 and Co M 9902 \\
\hline
\end{tabular}

These twelve genotypes along with susceptible check (93 A 145) were planted in a randomized block design with three replications at R.A.R.S during 2009-2010. The maximum number of shoots and the total number of dead hearts produced at 60 days after planting (DAP) in different genotypes were recorded and percent incidence of early shoot borer ( $\%$ deadhearts) calculated. The data were subjected to analysis of variance.

\section{Survival and development of ESB in the artificial diet compounded with dry shoot powder of different sugarcane genotypes}

The experiment was conducted in IPM laboratory, R.A.R.S. during March to May, 2010. Antibiosis component of resistance was measured by impregnating dry shoot powders of twelve selected genotypes and a susceptible check 93 A 145 into the artificial diet under in vitro conditions. Ten neonate larvae were released on to the artificial diet impregnated with respective shoot powder of selected sugarcane genotypes. Each treatment was replicated three times. In the rearing room, temperature was maintained at $28 \pm 1{ }^{\circ} \mathrm{C}, 60-70 \%$ relative humidity $(\mathrm{RH})$ and photo period of $12 \mathrm{~h}$.

For the preparation of shoot powder, shoots of sugarcane (93 A 145) were collected from 60 -day old plants raised under field conditions and dried in a hot air oven at $80^{\circ} \mathrm{C}$ for two days and powdered to $<80$ mesh size. The different ingredients utilized for preparation of the artificial diet were listed in Table 1. All the ingredients of fraction A (Table 1), except the sugarcane shoot powder, were blended for $1 \mathrm{~min}$. Field bean seeds $(100 \mathrm{~g})$ were soaked in water for $24 \mathrm{~h}$ and extruded manually from the seed coat and cooked before use. They were 
mixed with other ingredients of the medium (Fraction-A) except agar-agar, ascorbic acid, sugarcane shoot powder and ground to a paste. Agar was melted in $80 \mathrm{ml}$ of water (FractionB) and sugarcane shoot powder was added to it and the mixture was poured into the blender containing Fraction-A. All the constituents were blended for three minutes followed by autoclaving. Ascorbic acid was dissolved in $30 \mathrm{ml}$ of water and formaldehyde was added to medium just before it began to solidify. Medium was poured into plastic containers of 250 $\mathrm{ml}$ and also into plastic rearing trays having 10 cups of $25 \mathrm{ml}$ capacity.

Table 1. List of ingredients of artificial diet used for rearing of ESB in the laboratory

\begin{tabular}{llr}
\hline Sample No. & Ingredients & Quantity \\
\hline 1 & Shoot powder & $50.0 \mathrm{~g}$ \\
2 & Field bean & $100.0 \mathrm{~g}$ \\
Fraction- A & & \\
3 & Casein & $50.0 \mathrm{~g}$ \\
4 & Yeast & $16.0 \mathrm{~g}$ \\
5 & Vitamin capsules & $8.0 \mathrm{~g}$ \\
6 & Salt mixture & $5.0 \mathrm{~g}$ \\
7 & Ascorbic acid & $1.0 \mathrm{~g}$ \\
8 & Sorbic acid & $0.5 \mathrm{~g}$ \\
9 & MPH & $1.0 \mathrm{~g}$ \\
Fraction $-\mathrm{B}$ & & \\
9 & Agar agar & $8.0 \mathrm{~g}$ \\
10 & Formalin & $1.0 \mathrm{ml}$ \\
11 & Distilled water & $470 \mathrm{ml}$ \\
\hline
\end{tabular}

Source: Mukunthan \& Jayanthi, 2001

After cooling the medium for 2-3 $\mathrm{h}$ on the laboratory table, neonate larvae were released in to each cup using a fine brush. The plastic containers were kept in the rearing room in the dark for 2 days, because neonate larvae have a strong photopositive behaviour and settle better on the diet in darkness. Rearing rooms conditions were maintained as $28 \pm 1{ }^{\circ} \mathrm{C}, 60$ $70 \% \mathrm{RH}$ and $12 \mathrm{~h}$ light period per day.

There were three replications for studying larval development and measuring larval survival at 15 days after infestation $(250 \mathrm{ml}$ capacity cups having $150 \mathrm{~g}$ diet). Observations on larval survival and larval mass at 15 days after inoculation, duration of larval development were recorded and calculated the growth index of $C$. infuscatellus on artificial diet impregnated with different sugarcane genotypes.

$$
\text { Growth index }=\frac{\text { Mean percentage of larvae pupated }(\mathrm{n})}{\text { Mean larval period }(\mathrm{p})}
$$

\section{Statistical Analysis}

The data were analyzed using ANOVA. Treatment means were compared using least significance difference (LSD) at $\mathrm{P}<0.05$. 


\section{Studies on biochemical parameters of different sugarcane genotypes}

Biochemical differences among twelve selected genotypes and one known susceptible check 93 A 145 were examined using samples of sugarcane at 60 DAP. Collected leaf sheath and shoot samples were washed 3-4 times with distilled water. The washed samples were kept at $80{ }^{\circ} \mathrm{C}$ in an electrical hot air oven for $48 \mathrm{~h}$ and grounded into powder for the estimation of neutral detergent fibre (NDF), acid detergent fibre (ADF), cellulose, silica and lignin contents in shoot tissues. Fresh samples were utilized for estimation of total phenols, reducing and non-reducing sugars. Extractions were prepared following the method suggested by Mahadevan and Sridhar (1986).

\section{Estimation of total phenols}

Total phenols were determined by adopting the method suggested by Mallick and Singh (1980). Ethanol extract $(1 \mathrm{ml})$ was taken into a graduated test tube and $1 \mathrm{ml}$ of FolinCiocalteu reagent and $2 \mathrm{ml}$ of $20 \%$ Sodium carbonate were added. The mixture was heated in a water bath for about one minute and then cooled under running water. The sample was diluted to $25 \mathrm{ml}$ with distilled water. The absorbance of the resultant blue colour solution was read at $650 \mathrm{~nm}$ in a Spectronic-20. A reagent blank was maintained with $1 \mathrm{ml}$ of distilled water in place of ethanol-extract. Total phenols were calculated from Catechol standard curve and expressed in $\mathrm{mg} / \mathrm{g}$ of sample.

\section{Estimation of total sugars}

Total sugar content was estimated using the method suggested by Dubois et al. (1956). Ethanol extract $(0.2 \mathrm{ml})$ was taken into a volumetric flask and $1.8 \mathrm{ml}$ of distilled water and $0.25 \mathrm{ml}$ of $80 \%$ phenol were added. The sample was shaken and $5 \mathrm{ml}$ of conc. $\mathrm{H}_{2} \mathrm{So}_{4}$ was added immediately and allowed to stand for $30 \mathrm{~min}$. Per cent absorbance at $490 \mathrm{~nm}$ was measured using Spectronic-20 using a blank without sugar extract. The absorbance scale and sample values were corrected for the mean of three reaction blanks. Standard curve of glucose concentration versus absorbance was used to convert sample absorbance to sugar percentage. The average value of plant sample was recorded as the total sugar in $\mathrm{mg} / \mathrm{g}$ of sample.

\section{Estimation of reducing Sugars}

Reducing sugar content of the plant samples was estimated by adopting Nelson and Somogyi method (Krishnaveni et al., 1984). Ethanol extract (1 ml) was mixed with Copper reagent (1 $\mathrm{ml})$. The mixture was heated for $20 \mathrm{~min}$. in a water bath, cooled and arsenomolybdate (1 ml) reagent was added to the mixture. The intensity of blue colour of the mixture was read against a blank in Spectronic-20 at $520 \mathrm{~nm}$ and was expressed in terms of glucose equivalents. Standards with different concentrations (i.e. 25, 50, 75, 100 and 125) were prepared from the working standard and their absorbance was read by taking one $\mathrm{ml}$ aliquots.

Percent of total soluble sugars was calculated by using the formula:

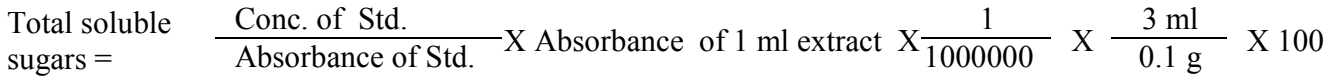




\section{Neutral detergent fibre (NDF) and Acid detergent fibre (ADF)}

NDF content of sugarcane genotypes was measured by using the method suggested by Goering and Van soest's (1970) and calculated by using the following formula.

$\operatorname{NDF}(\%)=\frac{\text { Wt. of oven dry crucible with sample }- \text { Wt. of oven dry crucible without }}{\text { sample }} \times 100$

Air dried sample ( $1 \mathrm{~g})$ was taken into a beaker of the refluxing apparatus, and acid detergent solution $(100 \mathrm{ml})$ and decahydro-naphthalene $(2 \mathrm{ml})$ were added. The ADF was extracted and estimated by Goering and Van soest's (1970) method.

\section{Cellulose, lignin and silica}

A crucible (sintered) containing ADF was filled with $\mathrm{H}_{2} \mathrm{SO}_{4}(72 \%)$ and stirred with glass rod to smoothen the paste and break the lumps. $\mathrm{H}_{2} \mathrm{SO}_{4}(72 \%)$ was added again and stirred at hourly interval till acid drained away. Thereafter, the contents were washed with hot water to make these free from acid. The residue in crucible was dried overnight at $100{ }^{\circ} \mathrm{C}$, weighed and then kept in muffle furnace at $500-550{ }^{\circ} \mathrm{C}$ for $3 \mathrm{~h}$. On cooling, the crucible was removed and the weight was measured. The cellulose, lignin and silica percentage were calculated as follows:

Cellulose $(\%)=\frac{\text { Loss with } 72 \% \mathrm{H}_{2} \mathrm{SO}_{4}}{\text { Weight of sample }} \times 100$

Lignin $(\%)=\frac{\text { Loss upon ignition after } 72 \% \mathrm{H}_{2} \mathrm{SO}_{4}}{\text { Weight of sample }} \times 100$

Silica $(\%)=\frac{\text { Weight of crucible with silica }- \text { Wt. of oven dry empty crucible }}{\text { Weight of sample }} \times 100$

Experimental design was completely randomized design (CRD) and the data were analyzed using ANOVA.

\section{RESULTS AND DISCUSSION}

\section{Field screening of different sugarcane genotypes against ESB}

The results of field screening of different genotypes for resistance to ESB revealed that the LS genotypes had less than 15\% dead hearts (DH) viz., Co 0110 (8.49\%), 98 A 165 (9.87\%), Co $6806(9.58 \%)$ and $98 \mathrm{~A} 125(8.01 \%)$ and the MS genotypes 97 A 85 (22.5\%), $2000 \mathrm{~A}$ 105 (24.29\%), 99 A 5 (24.23\%) and C0 62175 (26.33\%) had 15-30\%, whereas the HS genotypes 93A 11 (31.86\%), 99 A 33 (37.54\%), 94 A 124 (34.98\%), Co M 9902 (41.77\%) and the susceptible check, 93 A 145 (39.22\%) had more than 30\% incidence of ESB at 60 DAP. The plant samples of these thirteen genotypes were collected at 60 DAP and utilized for further studies in the present investigation (Table 2). 


\section{Effect of sugarcane genotypes incorporated in artificial diet on ESB}

Effect of least susceptible sugarcane genotypes incorporated in artificial diet on larval survival, larval mass, duration of larval development of $C$. infuscatellus in comparison with susceptible check, 93 A 145 are presented in Table 3.

Table 2. Percent germination and incidence of ESB (\% DH) in different genotypes at 60 DAP -2009-2010

\begin{tabular}{lcccc}
\hline Genotype & $\begin{array}{c}\text { Germination } \\
(\%)\end{array}$ & $\begin{array}{c}\text { Total shoots } \\
\text { At 60 DAP }\end{array}$ & $\begin{array}{c}\text { No. of Dead } \\
\text { hearts at 60 } \\
\text { DAP }\end{array}$ & $\begin{array}{c}\text { DH (\%) } \\
\text { at 60 DAP (*) }\end{array}$ \\
\hline LS genotypes & & & & \\
Co 0110 & 100.00 & 161.00 & 13.70 & $8.49(16.92)$ \\
98 A 165 & 92.90 & 125.00 & 12.30 & $9.87(18.25)$ \\
Co 6806 & 92.10 & 135.70 & 13.00 & $9.58(18.00)$ \\
98 A 125 & 95.90 & 104.00 & 8.30 & $8.01(16.42)$ \\
MS genotypes & & & & \\
97 A 85 & 95.40 & 146.70 & 33.00 & $22.50(28.28)$ \\
2000 A 105 & 97.50 & 70.00 & 17.00 & $24.29(29.72)$ \\
99 A 5 & 99.40 & 263.3 & 63.8 & $24.23(29.25)$ \\
Co 62175 & 91.30 & 93.70 & 24.70 & $26.33(30.85)$ \\
HS genotypes & & & & \\
93 A 11 & 86.30 & 166.30 & 53.00 & $31.86(34.35)$ \\
99 A 33 & 90.40 & 97.70 & 36.70 & $37.54(37.78)$ \\
94 A 124 & 90.00 & 223.00 & 78.00 & $34.98(36.25)$ \\
Co M 9902 & 100.00 & 135.70 & 56.70 & $41.77(40.30)$ \\
93 A 145 & 92.90 & 145.30 & 57.00 & $39.22(38.78)$ \\
(Susceptible check) & & & & \\
CD (5\%) & NS & 15.8420 & 6.3425 & 1.7950 \\
CV\% & & 9.46 & 7.53 & 5.69 \\
\hline
\end{tabular}

LS: least susceptible; MS: moderately susceptible; HS: highly susceptible Figures in parenthesis are transformed values

\section{Effect on larval survival}

Larval survival was significantly low on artificial diet incorporated with LS genotypes (26\% on 98 A 125 to $34 \%$ on Co 6806) and more on HS genotypes (64-84.2\%) as compared to susceptible check (84\%) at 15 DAI. This clearly indicates the adverse effect of LS genotypes on larval survival of ESB (Table 3). The LS genotype, 98 A 125 affected larval survival in artificial diet and recorded the lowest survival at 15 DAI (26\%). Similar results have been obtained by earlier workers with reference to C. partellus on maize (Durbey \& Sarup 1985; Sharma \& Chatterji 1971a) who inferred that the mortality of C. partellus on resistant maize genotypes might be due to the accumulation of toxins or lack of very essential nutrients or lack of feeding stimulant including the possibility of presence of some feeding deterrent and indicating the presence of antibiosis mechanism in the shoot tissues. Similar results have 
been obtained by earlier workers with reference to larval survival on sorghum (Kalode \& Pant, 1967a; Lal \& Sukhani, 1979; Lal \& Pant, 1981; Singh \& Verma, 1988; Taneja \& Woodhead, 1989) who reported that mortality of C. partellus.

Table 3. Effect of artificial diet impregnated with different genotypes on larval survival and larval mass of ESB-2009-2010

\begin{tabular}{lcccc}
\hline Genotype & $\begin{array}{c}\text { Larval } \\
\text { survival (\%) } \\
\text { at 15 DAI }\end{array}$ & $\begin{array}{c}\text { Larval mass } \\
(\mathbf{m g}) * \text { at 15 } \\
\text { DAI }\end{array}$ & $\begin{array}{c}\text { Larval } \\
\text { period } \\
\text { (days) }\end{array}$ & $\begin{array}{c}\text { Growth } \\
\text { index (n/p) }\end{array}$ \\
\hline LS genotypes & & & & \\
Co 0110 & 30.00 & 83.0 & 21.98 & 1.73 \\
98 A 165 & 29.80 & 82.2 & 21.32 & 1.69 \\
Co 6806 & 34.00 & 84.6 & 21.14 & 1.61 \\
98 A 125 & 26.00 & 79.9 & 22.26 & 1.53 \\
MS genotypes & & & & \\
97 A 85 & 50.00 & 94.8 & 21.38 & 2.39 \\
2000 A 105 & 52.00 & 99.2 & 20.40 & 2.67 \\
99 A 5 & 56.00 & 117.2 & 21.14 & 2.74 \\
Co62175 & 60.00 & 124.3 & 20.10 & 2.94 \\
HS genotypes & & & & \\
93 A 11 & 64.00 & 149.3 & 18.78 & 3.51 \\
99 A 33 & 72.00 & 152.0 & 17.72 & 3.72 \\
94 A 124 & 76.00 & 157.8 & 17.22 & 3.89 \\
CoM 9902 & 84.20 & 179.9 & 16.56 & 4.71 \\
93 A145 (Susceptible & 84.00 & 178.4 & 16.64 & 4.51 \\
check) & & & & \\
CD (5\%) & 5.9911 & 1.7935 & 0.2342 & 0.3546 \\
CV\% & 8.22 & 1.16 & 0.70 & 0.48 \\
\hline
\end{tabular}

DAI : days after inoculation; * mean of ten individuals

LS: least susceptible; MS: moderately susceptible; HS: highly susceptible

\section{Effect on larval mass}

Larval mass of ESB was considerably low, ranging from 79.9 to $84.6 \mathrm{mg}$ per larva when reared on artificial diet impregnated with the shoot powders of four LS genotypes (98 A 125, $98 \mathrm{~A} 165$, Co 0110 and Co 6806) at 15 DAI whereas $178.4 \mathrm{mg}$ per larva was recorded in the susceptible check, 93 A 145 at 15 DAI (Table 3). The difference was two times more than that of the susceptible check, 93 A 145. The HS genotype, Co M 9902 recorded highest larval mass (179.9 mg per larva) and it was on par with the susceptible check. Larvae reared on MS genotypes (97 A 85, 2000 A 105, 99 A 5 and Co 62175) too recorded significantly lower mass compared to HS genotypes and susceptible check, 93 A $145(\mathrm{P}<0.05)$. All four LS genotypes have been found to exercise adverse effect on larval mass of early shoot borer when they were incorporated in artificial diet in the laboratory conditions. Similar results, 
with reference to C. partellus on sorghum have been reported by Jotwani et al. (1978) and Taneja and Woodhead (1989).

\section{Effect on larval period}

There were highly significant differences of larval period among the resistant sugarcane genotypes and the susceptible check. In general, duration of early shoot borer larvae reared on the diet incorporated with powdered shoots of LS and MS genotypes was longer compared to the HS genotypes and the susceptible check, 93 A 145 (Table 3). On artificial diet incorporated with the LS genotypes, 98 A 125, the larval duration has been significantly prolonged, 6 days longer than in the susceptible check. However, in the other LS genotypes it ranged from 4-5 days longer than in the check as compared to the susceptible check, $93 \mathrm{~A}$ 145. The four MS genotypes, 97 A 85, 2000 A 105, 99 A 5 and Co 62175 also showed significantly prolonged larval duration when compared to susceptible check, 93 A 145 . On artificial diet incorporated with four HS genotypes, the larval duration has been shortened and it ranged $20.56-21.78$ days. The HS genotype, Co M 9902 has recorded 20.56 days of larval duration which was significantly on par with the susceptible check, 93 A 145 . The present findings are in agreement with Kalode and Pant (1967a), Sharma and Chatterji (1971a), Jotwani et al. (1978) and Durbey and Sarup (1984, 1985).

\section{Effect on growth index}

The LS genotype, 98 A 125 showed the lowest growth index (1.53) whereas the HS genotype, Co M 9902 showed the highest growth index (4.71) which was twice that of Co 0110 (Table 3). The MS genotypes also had significant adverse effect on growth index and recorded 2.39 to 2.94 as against the susceptible check, 93 A 145. Higher mean larval period (p) and lower number of larvae pupated (n) might have contributed to lower growth index in LS genotypes. However, p-factor had been more contributive than n-factor. Sharma et al. (2007a) reported that in case of sugarcane top borer, Chilo auricilius, mean larval survival was lowest on LS group (57.91) compared to 62.08 in MS and 76.67 per cent in HS resulting into highest mean growth index on HS (1.32) followed by MS (0.96) and LS genotypes $(0.83)$.

\section{Biochemical analysis of sugarcane genotypes}

The studies were undertaken on the major chemical constituents of leaf sheath and shoot tissues of LS, MS and HS genotypes of sugarcane at 60 DAP to determine the biochemical basis which may be associated with resistance to ESB and data were analyzed to find correlations between various chemical constituents and susceptibility to ESB in different sugarcane genotypes and the results are presented hereunder (Tables 4, 5, 6).

\section{Total sugar and reducing sugar}

The amounts of total sugar in shoot tissues of all genotypes were higher than in leaf sheath tissues irrespective of genotype. It was highest (8.98\%) in shoot tissues of HS genotype, Co M 9902 and was lowest (5.34\%) in LS genotype, 98 A 125 as compared to $8.95 \%$ in the susceptible check, 93 A 145 (Table 4). Total sugars in leaf sheath also showed significant difference among genotypes and the differences were ranged from 4.18 to $4.97 \%$ in LS. HS genotypes had $4.85 \%$ in susceptible check. An increasing trend of total sugar contents of both shoot and leaf sheath tissues of different genotypes was observed with increase in 
susceptibility of hosts to ESB and correlated positively with the ESB susceptibility ( $\mathrm{r}=0.96$ and 0.88 in shoot and leaf sheath, respectively) (Table 6 and Fig. 1).

A similar trend was observed with respect to reducing sugars (Table 4). The shoots of LS genotypes contained significantly less $(0.078-0.089 \%)$ amount of reducing sugars and it increased in MS genotypes (0.096-0.112\%). It was the highest $(0.105-0.173 \%)$ in HS genotypes and $0.179 \%$ in the susceptible check, 93 A 145. Similar trend was also observed in case of reducing sugars in leaf sheaths (Table 6). The differences in reducing sugar content in shoot and leaf sheath tissues among the different genotypes were significant and showed positive correlation with ESB susceptibility ( $\mathrm{r}=0.89$ and 0.82 ) (Table 6).

Table 4. Total sugars, reducing sugars and phenol contents in the leaf sheath and the shoot of tissues of different genotypes at 60 DAP -2009-10

\begin{tabular}{|c|c|c|c|c|c|c|}
\hline \multirow{2}{*}{ Genotype } & \multicolumn{2}{|c|}{$\begin{array}{c}\text { Total sugars } \\
(\%)\end{array}$} & \multicolumn{2}{|c|}{$\begin{array}{c}\text { Reducing Sugars } \\
(\%)\end{array}$} & \multicolumn{2}{|c|}{$\begin{array}{l}\text { Phenol } \\
\text { (mg/g) }\end{array}$} \\
\hline & Shoot & $\begin{array}{c}\text { Leaf } \\
\text { sheath }\end{array}$ & Shoot & $\begin{array}{c}\text { Leaf } \\
\text { sheath }\end{array}$ & Shoot & $\begin{array}{c}\text { Leaf } \\
\text { sheath }\end{array}$ \\
\hline \multicolumn{7}{|l|}{ LS genotypes } \\
\hline Co 0110 & 5.85 & 4.19 & 0.081 & 0.073 & 11.76 & 12.82 \\
\hline 98 A 165 & 6.38 & 4.24 & 0.083 & 0.072 & 11.20 & 11.86 \\
\hline Co 6806 & 6.25 & 4.22 & 0.089 & 0.069 & 11.78 & 11.9 \\
\hline 98 A125 & 5.34 & 4.18 & 0.078 & 0.063 & 12.30 & 13.03 \\
\hline \multicolumn{7}{|l|}{ MS genotypes } \\
\hline 97 A 85 & 7.40 & 4.19 & 0.096 & 0.068 & 10.27 & 11.77 \\
\hline 2000 A 105 & 7.85 & 4.67 & 0.109 & 0.073 & 10.14 & 10.94 \\
\hline 99 A 5 & 7.34 & 4.29 & 0.098 & 0.070 & 9.9 & 10.93 \\
\hline Co 62175 & 6.93 & 4.68 & 0.112 & 0.077 & 9.92 & 11.09 \\
\hline \multicolumn{7}{|l|}{ HS genotypes } \\
\hline 93 A 11 & 8.57 & 4.74 & 0.135 & 0.084 & 9.12 & 10.85 \\
\hline 99 A33 & 7.82 & 4.55 & 0.105 & 0.079 & 9.2 & 12.24 \\
\hline 94 A124 & 8.83 & 4.82 & 0.157 & 0.079 & 8.94 & 11.03 \\
\hline Co M 9902 & 8.98 & 4.97 & 0.173 & 0.082 & 7.68 & 9.43 \\
\hline $\begin{array}{l}93 \text { A } 145 \\
\text { (susceptible check) }\end{array}$ & 8.95 & 4.85 & 0.179 & 0.079 & 8.87 & 9.22 \\
\hline $\mathrm{CD}(5 \%)$ & 0.0284 & 0.0304 & 0.001 & 0.001 & 0.0588 & 0.012 \\
\hline $\mathrm{CV} \%$ & 0.23 & 0.40 & 0.50 & 0.84 & 0.35 & 0.06 \\
\hline
\end{tabular}

DAP : Days after planting

LS: least susceptible; MS: moderately susceptible; HS: highly susceptible

Similar relation was reported by Rao and Rao (1961) for C. auricilius. Kalode \& Pant (1967b) found that sorghum varieties susceptible to Chilo zonellus Swinhoe contained higher percentage of sugars than resistant ones. Sharma \& Chatterji (1971b) and Knapp et al. (1965) observed 50\% more reducing sugars in susceptible varieties to corn earworm. Since, sugar is 
considered as one of the vital nutrients in plants and also sugar contents reflect the metabolic state of the sugarcane shoot, the differences in the relative amounts of sugars between different genotypes with differential susceptibilities to ESB indicate that these compounds might act as phagostimulants to $C$. infuscatellus feeding on sugarcane.

\section{Total Phenols}

Leaf sheaths contained higher total phenols than the shoot tissues (Table 4). The LS genotypes contained higher shoot tissue phenols (11.2-12.3 mg/g) than MS genotypes (9.9$10.27 \mathrm{mg} / \mathrm{g}$ ) and HS genotypes (7.68-9.2 mg/g) as against $8.87 \mathrm{mg} / \mathrm{g}$ in susceptible check, 93 A 145. The LS genotype, 98 A 125 contained maximum amount $(12.3 \mathrm{mg} / \mathrm{g})$ and minimum was in HS genotype, Co M $9902(7.68 \mathrm{mg} / \mathrm{g})$. In leaf sheath tissues also, maximum phenol content was recorded in LS genotypes and minimum in HS genotypes. Phenol contents of both shoot and leaf sheath tissues showed significant differences among different genotypes and also showed a significantly inverse correlation with ESB, C. infuscatellus susceptibility. The LS genotypes recorded higher phenol contents than MS and HS genotypes (Table 4 \& Fig. 1).

Phenol contents of both shoot $(\mathrm{r}=-0.97)$ and leaf sheath tissues $(\mathrm{r}=-0.80)$ showed a significantly inverse correlation with ESB, C. infuscatellus susceptibility (Table 6). Phenolic compounds have been implicated in the resistance of a number of plant species to various insect- pests like shoot borer in sugarcane. Phenols are one of the most important group of plant defense chemicals responsible for antifeedant and/or antibiotic effects on insects (Kennedy \& Nachiappan, 1992; Shroff, 1996). Aphid in wheat (Niraz et al., 1987), whitefly in cotton (Buttler et al., 1992), aphid on mustard (Sachan \& Achan, 1991) and stem borer $C$. partellus in maize (Kabre \& Ghorpade, 1998) have also recorded similar observation in relation to stem resistance.

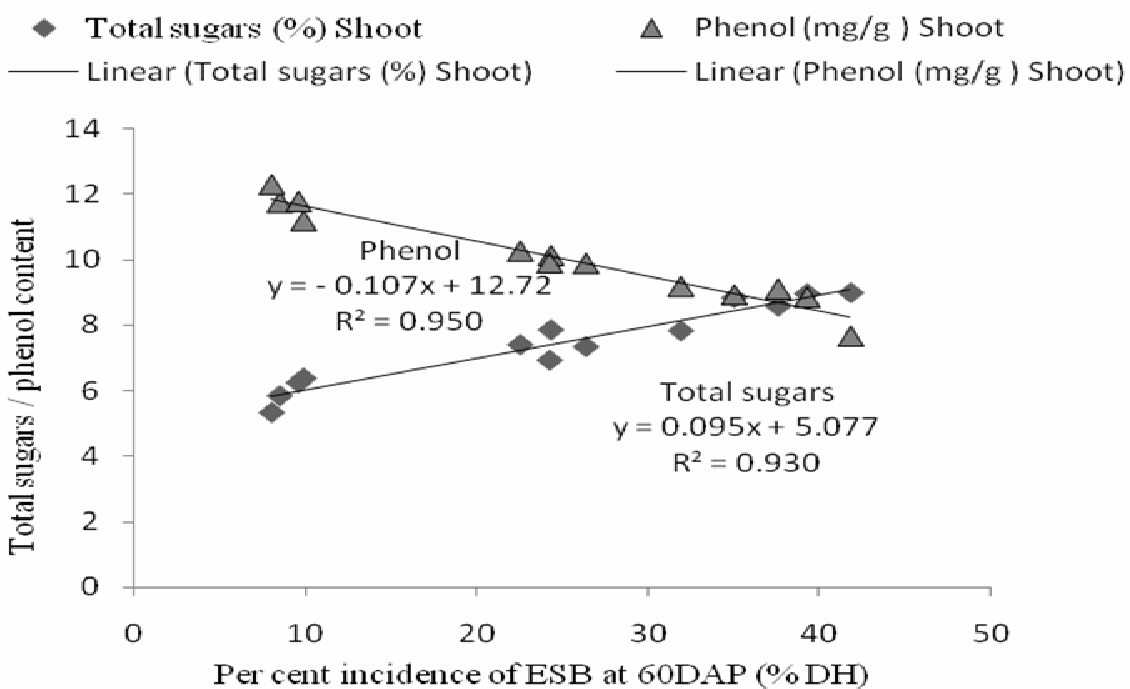

Fig. 1. Correlation between total sugars and phenol contents in shoot tissues of different sugarcane genotypes and ESB incidence at 60 DAP NDF and ADF 
NDF was higher (54.79-57.26\%) in shoot tissue of least susceptible genotypes (Table 5). It was $47.21-50.65 \%$ in MS and 45.07-50.11\% in HS genotypes. The genotype, 98 A 125 had the highest NDF (57.26\%) while the lowest (46.42\%) was in susceptible check, 93 A 145. The differences in NDF content in shoot tissues among the susceptibility groups were more apparent, witnessing a gradual decline in NDF content with increase in susceptibility of hosts to ESB indicating significant inverse relationship $(\mathrm{r}=-0.92)$ between NDF and susceptibility of the shoots to ESB infestation (Table 6 and Fig. 2).

The ADF content in shoot tissue varied from a lowest of 20.7\% in HS genotype, Co M 9902 to the highest of $27.2 \%$ in LS genotype, 98 A125 as compared to $20.83 \%$ in the susceptible check, 93 A 145 (Table 5). The ADF contents in shoot tissue of least, moderately and highly susceptible genotypes were estimated at $24.09-27.20 \%, 20.51-22.81 \%$ and $20.70-22.11 \%$, respectively. A gradual decline in ADF content with increase in susceptibility of hosts to ESB indicated a significantly negative correlation with susceptibility. The percentage of $\mathrm{ADF}$ and the NDF were found to be much lower in genotypes of high susceptibility and therefore, showed a significantly negative correlation $(\mathrm{r}=-0.86)$ with ESB infestation (Table 6 \& Fig. 2).

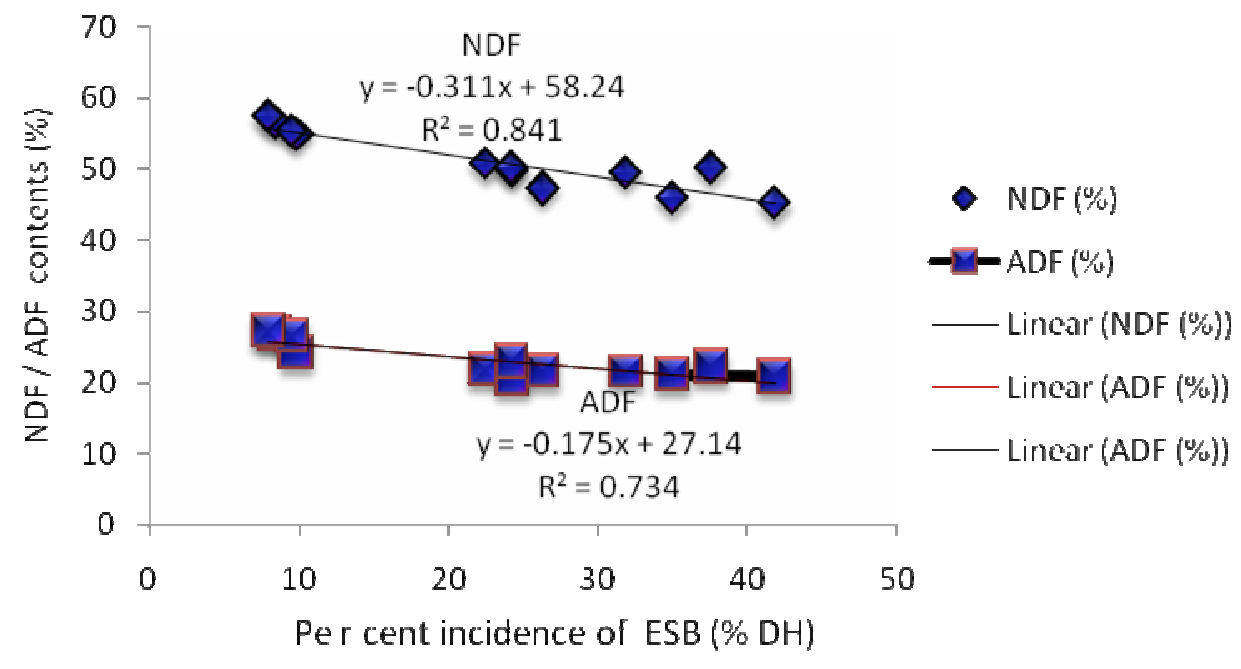

Fig. 2. Correlation between NDF, ADF contents (\%) of different sugarcane genotypes and ESB incidence at 60 DAP

\section{Cellulose, lignin and silica}

Cellulose, lignin and silica contents in shoot tissues at 60 DAP revealed that the stalk tissue of least susceptible genotype, 98 A 125 recorded relatively higher amount of cellulose (28.58\%) than other LS genotypes (Table 5). The MS genotypes contained 22.43-25.10\% cellulose and HS genotypes had 23.95-18.97\%. This indicates a decreasing trend in cellulose content in shoot tissues in genotypes with the susceptibility showing a negative correlation $(\mathrm{r}=-0.90)$ with ESB susceptibility (Tables 5 and 6$)$. 
Similarly, lignin content of shoot was maximum (7.09\%) in LS genotype, 98 A 125 and minimum (4.96\%) in HS genotype, Co M 9902 (Table 5). The lignin percentage in shoot tissue of LS, MS and HS genotypes varied from 6.61 to $7.09 ; 5.99$ to 6.38 and 4.96 to 5.69, respectively as compared to $5.11 \%$ in the susceptible check, 93 A 145 indicating a negative correlation between lignin content and ESB susceptibility ( $\mathrm{r}=-0.94)$ (Table 6).

Table 5 revealed that the silica content in shoot tissues of LS genotypes was significantly high (1.33-1.53\%) as compared to the susceptible check, 93 A $145(0.79 \%)$. The shoot tissues of MS genotypes also contained significantly more silica content (1.09-1.24\%) than HS genotypes $(0.75-0.98 \%)$. The differences in silica content in different groups of genotypes were significant $(\mathrm{P}<0.05)$ and showed decreasing trend with susceptibility and exhibited significantly inverse relationship with ESB susceptibility $(\mathrm{r}=-0.96)$ (Table 6).

Table 5. Effect of NDF, ADF, cellulose, lignin and silica contents in shoot tissues of different genotypes on the incidence of ESB at 60 DAP-2009-2010

\begin{tabular}{lccccc}
\hline Genotype & $\begin{array}{c}\text { NDF } \\
(\mathbf{\%})\end{array}$ & $\begin{array}{c}\text { ADF } \\
(\mathbf{\%})\end{array}$ & $\begin{array}{c}\text { Cellulose } \\
(\mathbf{\%})\end{array}$ & $\begin{array}{c}\text { Lignin } \\
(\mathbf{\%})\end{array}$ & $\begin{array}{c}\text { Silica } \\
(\mathbf{\%})\end{array}$ \\
\hline LS genotypes & & & & & \\
& & & & & \\
Co 0110 & 56.40 & 26.82 & 27.81 & 6.95 & 1.47 \\
98 A 165 & 54.79 & 24.09 & 28.38 & 7.06 & 1.51 \\
Co 6806 & 55.29 & 26.41 & 25.95 & 6.61 & 1.33 \\
98 A125 & 57.26 & 27.20 & 28.58 & 7.09 & 1.53 \\
MS genotypes & & & & & \\
97 A 85 & & & & & \\
2000 A105 & 50.65 & 21.82 & 24.74 & 6.38 & 1.24 \\
99 A 5 & 49.60 & 20.51 & 25.10 & 6.31 & 1.21 \\
Co 62175 & 47.21 & 21.61 & 22.43 & 5.99 & 1.09 \\
HS genotypes & 50.11 & 22.81 & 23.82 & 6.25 & 1.19 \\
& & & & & \\
93 A 11 & & & & & \\
99 A33 & 50.11 & 22.11 & 22.48 & 5.49 & 0.92 \\
94 A124 & 49.41 & 21.47 & 23.95 & 5.69 & 0.98 \\
Co M 9902 & 45.84 & 21.07 & 20.62 & 5.36 & 0.87 \\
93 A 145 & 45.07 & 20.70 & 18.97 & 4.96 & 0.75 \\
(Susceptible check) & 46.42 & 20.83 & 19.06 & 5.11 & 0.79 \\
CD (5\%) & & & & & \\
CV\% & 0.0442 & 0.0287 & 10.3744 & 0.0107 & 0.0104 \\
\hline & 0.05 & 0.07 & 19.46 & 0.14 & 0.54 \\
\hline
\end{tabular}

NDF : Neutral detergent fibre ADF: Acid detergent fibre DAP : Days After Planting

LS: least susceptible; MS: moderately susceptible; HS: highly susceptible 
Table 6. Correlation between biochemical constituents of different genotypes and ESB incidence at 60 DAP -2009- 2010

\begin{tabular}{|c|c|c|}
\hline \multirow[t]{2}{*}{ Biochemical constituent } & \multicolumn{2}{|c|}{$\begin{array}{c}\text { Correlation with ESB incidence } \\
(\% \mathrm{DH}) \text { at } 60 \text { DAP }\end{array}$} \\
\hline & Leaf sheath & Shoot \\
\hline Reducing sugar (\%) & $0.89 *$ & $0.82 *$ \\
\hline Phenol (mg/g) & $-0.97 *$ & $-0.80 *$ \\
\hline Silica (\%) & -- & $-0.96^{*}$ \\
\hline Cellulose $(\%)$ & -- & $-0.90 *$ \\
\hline Lignin $(\%)$ & -- & $-0.94 *$ \\
\hline Neutral detergent fibre (NDF) (\%) & -- & $-0.92 *$ \\
\hline Acid detergent fibre (ADF) (\%) & -- & $-0.86 *$ \\
\hline
\end{tabular}

*Significant at $5 \%$ level

The LS genotypes had a relatively higher amount of cellulose, lignin and silica, the basic constituents of NDF and ADF that had a supportive function in cell wall thickening and hardening of plant tissues, thereby, help to avoid attack by the ESB. Rao (1962) reported similar results: a negative correlation between silica content and shoot borer incidence. Varieties with a high number of silica cells per unit area in the leaf-sheath portion, 2-3 inches from the base of the shoots are resistant to shoot borer infestation. Khurana and Verma (1983) with reference to C. partellus in sorghum observed that natural detergent fibre, acid detergent fibre, cellulose, lignin, tannin and total phenols in 50 day old plants had negative correlation with susceptibility to C. partellus in sorghum. Similarly, Sharma et al. (2007b) reported negative association between biochemical constituents like the NDF, ADF, phenol, cellulose and lignin content in leaf sheath and stalk with susceptibility to top borer $C$. auricilius in sugarcane whereas positive correlation had been reported between total sugars, reducing sugars and top borer susceptibility.

\section{CONCLUSIONS}

The present study revealed reduced larval survival, reduced larval mass and prolonged larval developments of ESB in least susceptible genotypes compared to highly susceptible genotypes as well as susceptible check, 93 A 145. This is mainly due to the presence of antibiosis mechanism in the shoot tissues of LS genotypes either by accumulation of toxins or lack of essential nutrients or lack of feeding stimulant including the possibility of presence of some feeding deterrents.

Biochemical analysis of different sugarcane genotypes indicated that lower total sugar, reducing sugar contents and higher phenol, NDF, ADF, cellulose, lignin, silica and cellulose contents in the shoot tissues of LS genotypes (Co 0110, Co 6806, 98 A 125, and 98 A 165) has increased its resistance to early shoot borer by influencing the biology, establishment of early shoot borer and played an important role in the antibiosis mechanism. 


\section{ACKNOWLEDGEMENTS}

The authors are thankful to the Director of Research, A.N.G. Ranga Agricultural University, Hyderabad, India and Associate Director of Research, R.A.R.S., Anakapalle, India for providing all the facilities during the research work.

\section{REFERENCES}

Avasthy, P.N. and Tiwari, N.K. (1986). The shoot borer Chilo infuscatellus Snellen. pp. 6992. In: David, H. Eswaramoorthy, S. and Jayanthi, R. (Eds.). Sugarcane Entomology in India Sugarcane Breeding Institute, Coimbatore.

Buttler, N.S. Vir, Gurdeep Kaur, B.K., Singh, T.H. and Raheja, R.K. (1992). Biochemical basis of resistance to whitefly, Bemisia tabaci Genn. (Aleyrodidae: Hemiptera) in cotton. Trop. Agric. 69, 119-122.

Chaudhary, J.P. (1973). Some important insect pests of Sugarcane. Haryana Agricultural University Magazine. pp. 78-83.

Dubois, M., Gilles, K.A., Hamilton, J.K., Rehers, P.A. and Smith, F. (1956). Calorimetric method for determination of sugars and related substances. Analytical Chem. 28, 350-356.

Durbey, S.L. and Sarup, P. (1984). Biological parameters related to antibiosis mechanism of resistance in maize varieties to Chilo partellus (Swinhoe). J. Entomol. Res. 9, 201-206.

Durbey, S.L., and Sarup, P. (1985). Antibiosis due to powdered dry plant material of maize varieties incorporated in artificial diet for rearing of the stalk borer, Chilo partellus (Swinhoe). J. Entomol. Res. 9, 201-206.

Goering, H.K. and Vansoest, P.J. (1970). Forage fibre analysis, apparatus, reagents, procedures and some applications. Agriculture Hand Book No. 379. Department of Agriculture, Washington, D.C.

Jotwani, M.G. Chaudhari, S. and Singh, S.P. (1978). Mechanism of resistance to Chilo partellus (Swinhoe) in sorghum. Indian J. Entomol. 40, 273-276.

Kabre, G.B. and Ghorpade, S.A. (1998). Studies on association of some chemical constituents of maize genotypes with susceptibility of stem borer. J. Maharashtra Agricultural University, 22, 301-304.

Kalode, M.B. and Pant, N.C. (1967a). Effect of host plants on the survival, development and behaviour of Chilo partellus (Swinhoe) under laboratory conditions. Indian J. Entomol. 29, 48-57.

Kalode, M.B. and Pant, N.C. (1967b). Studies on the amino acids, nitrogen, sugar and moisture content of maize and sorghum varieties and their relation to Chilo partellus (Swinhoe) resistance. Indian J. Entomol. 29, 139-144.

Kennedy, F.J.S. and Nachiappan, R. (1992). Certain anatomical physical and chemical basis for differential preference of early shoot borer (Chilo infuscatellus Snellen) in sugarcane. 
International symposium on crop protection. Mededelingen van de faculteitlandbouwweten- schappen, Rijks University. Gent. 57(3A), 637-644.

Khan, M.Q. and Krishnamurthy, R. (1956). Assessment of loss due to Chilotraea infuscatellus Snellen in sugarcane. Proc. Int. Soc. Sugarcane Techno. 9, 870-879.

Khurana, A.D. and Verma, A.N. (1983). Some biochemical plant characters in relation to susceptibility of sorghum to stem borer and shoot fly. Indian J. Entomol. 45, 29-37.

Knapp, J.L., Hedin, P.A. and Douglas, W.A. (1965). Amino acids and reducing sugars in silks of corn resistant or susceptible to corn ear worm. Annals of Entomo. Soci. of Am. 58(3), 401-402.

Krishnaveni, S., Balsubramanian, H. and Sadasivam, S. (1984). Food Chem., 15, 229.

Lakshminarayana, K. (1983). Pest Management in Andhra Pradesh. pp. 63-70. In: Balasubramanyan, $M$ and Solayappan A.R. (Eds.). Sugarcane Pest Management in India. Tamil Nadu Cooperative Sugar Federation, Madras.

Lal, G. and Pant, J.C. (1981). Laboratory and field testing for resistance in maize and sorghum varieties to Chilo partellus (Swinhoe). Indian J. Entomol. 42, 606-61.

Lal, G. and Sukhani, T.R. (1979). Development of sorghum stem borer Chilo partellus (Swinhoe) larvae on some resistant lines of sorghum. Bull. Entomol. 20, 67-70.

Mahadevan, A. and Sridhar, R. (1986). Methods in physiological plant pathology. Third edition. Sivakami publications, Madras, pp. 190-192.

Mallik, C.P. and Singh, M.B. (1980). Estimation of phenols in plant enzymology and histo enzymology, Kalyani publishers New Delhi, pp. 286.

Mukunthan, N. and Jayanthi, R. (2001). Entomology and Nematology. Annual Report, Sugarcane Breeding Institute, Coimbatore, pp. 51-52.

Niraz, S. Leszczynski, B. Ciepiela, A. and Urabanska, A. (1987). The importance of various plant chemical compounds to constitute aphid resistance in winter wheats. Roczniki Nauk Rolniczych. E (Ochrona Roslin). 17, 61-75.

Patil, A.S. and Hapase, D.G. (1981). Research on sugarcane borers in Maharashtra State. Proceedings of National Symposium on stalk borer. pp 165-175.

Prasad Rao, V.L.V., Sambasiva Rao, S. and Venugopala Rao, N. (1991). Factors influencing infestation of early shoot borer, C. infuscatellus in sugarcane. Cooperative Sugar. 22, 515521.

Rao, D.V.S. (1962). Studies on the resistance of sugarcane to the early shoot borer, Chilotraea infuscatellus Snell. M.Sc Thesis. Andhra University, Visakhapatnam, India.

Rao, D.V.S. and Rao, C.K. (1961). Preliminary studies on varietal resistance of sugarcane to infestation by the early shoot borer, Chilotraea infuscatellus Snell. Andhra Agricultural J. 8, 140-146. 
Sachan, S.K. and Sachan, G.C. (1991). Relation of some biochemical characters of Brassica juncea (Cossan) to susceptibility to Lipaphis erysimi (K.). Indian J. Entomol. 53, 218-225.

Seshagiri Rao and Krishnamurthy Rao, M.M. (1973). Studies on loss in yield of sugarcane due to shoot borer incidence, Chilo infuscatellus Snellen (Pyralidae: Lepidoptera). Indian Sugar. 22, 867-871.

Sharma, B.L., Saroj, J. and Chaudhary, O.P. (2007a). Studies on the prevalence of antibiosis mechanism of resistance and different tolerance characteristics against stalk borer, Chilo auricilius Dudgeon in sugarcane. Cooperative Sugar. 39(2), 33-40

Sharma, B.L. Saroj, J. and Chaudhary, O.P. (2007b). Biochemical basis of host plant resistance in sugarcane varieties against stalk borer, Chilo auricilius Dudgeon. Cooperative Sugar. 39(1), 29-39.

Sharma, V.K. and Chatterji, S.M. (1971a). Survival and developmental behavior of Chilo zonellus (Swin.) on some selected germplasm of maize under laboratory conditions. Indian J. Entomol. 33, 384-395.

Sharma, V.K. and Chatterji, S.M. (1971b). Studies on some chemical constituents in relation to differential susceptibility of some maize germplasms to Chilo zonellus (Swinhoe). Indian J. Entomol. 33, 419-424.

Shroff, D. (1996). Studies on the phonetic and biochemical characteristics of sugarcane in relation to susceptibility to C. infuscatellus. M.Sc. Thesis, Haryana Agricultural University, Hisar.

Singh, S.P. and Verma, A. (1988). Antibiosis mechanism of resistance to stem borer, Chilo partellus (Swinhoe). Indian J. Entomol. 42, 473-48.

Taneja, S.L. and Woodhead, S. (1989). Mechanisms of stem borer resistance in sorghum Proceedings of the International Workshop on Sorghum Stem borers, November 17-20 1987, ICRISAT Center, India International Crops Research Institute for the Semi Arid Tropics, Patencheru, A P 502 324, India. pp. 137-143. 